\title{
CAI is DOA
}

\section{Daniel S. Hamilton ${ }^{1}$}

Received: 23 April 2021 / Revised: 23 April 2021 / Accepted: 26 May 2021 /

Published online: 12 June 2021

(c) The Author(s), under exclusive licence to Springer-Verlag GmbH Germany, part of Springer Nature 2021

\begin{abstract}
The Comprehensive Agreement on Investment (CAI) that was borne but not formally blessed by China and the European Union in late December 2020 is unlikely to survive in its current form, if it survives at all. In fact, there is good reason to believe that the CAI is DOA - dead on arrival - due to EU sanctions and Chinese countersanctions related to China's persecution of its Uyghur minority; criticism of the negotiated agreement; and changing political calculations by Beijing and among EU member states.
\end{abstract}

The Comprehensive Agreement on Investment (CAI) that was borne but not formally blessed by China and the European Union in late December 2020 is unlikely to survive in its current form, if it survives at all. In fact, there is good reason to believe that the CAI is DOA - dead on arrival.

The CAI is in trouble for a host of reasons. Perhaps the most important is that Western nations have taken a stand opposing China's persecution and internment of Uyghurs in Xinjiang. Coordinated sanctions imposed by the United States, the European Union, the UK and Canada in March 2021 on specific Chinese officials and a Chinese security organization implicated in these human rights abuses are a sign that the EU is lifting its sights and is more likely to engage with democratic allies and partners to address the China challenge than to set off on unilateral commercial adventures with Beijing. Agreement by Washington and Brussels to resume and lift their bilateral dialogue on China is also likely to place the CAI within a broader transatlantic strategic discussion on China.

China's furious retaliation against EU sanctions has also made it highly unlikely that the CAI will be ratified anytime soon by the European Parliament or approved by any number of EU member states. Beijing announced it was sanctioning the EU Council's Political and Security Committee, which is comprised of 27 EU

Daniel S. Hamilton

dan.hamilton@wilsoncenter.org

1 Woodrow Wilson International Center for Scholars/Johns Hopkins University School of Advanced International Studies, Washington, DC, USA 
member-state ambassadors. It has banned five members of the European Parliament (MEPs) and various European scholars and think tankers from entering China or "doing business" with it. Hundreds of MEPs have made it clear that CAI has no chance of ratification unless the sanctions are ended and EU concerns about China's human rights abuses are addressed by Beijing. EU trade commissioner Valdis Dombrovskis has acknowledged that the ratification process cannot be separated from broader EU-China dynamics.

Moreover, the EU-China row over Beijing's human rights abuses casts an unfavorable glare on the CAI's weak provisions on this very topic. Even before the current dustup, at least one-third of EU member states and perhaps 400 MEPs had expressed concerns that in negotiating the deal the European Commission had failed to secure meaningful Chinese pledges to ratify four core conventions of the International Labor Organization (ILO) that commit states parties not to engage in forcedlabor practices and to guarantee free association and collective bargaining. In the CAI, Beijing only agreed to make an effort "to pursue" ratification of these conventions. Since China is a one-party Leninist state, it could ratify those provisions tomorrow if the Chinese Communist Party wanted to do so. Unfortunately, it does not.

Supporters of the deal within the EU believed they had time to massage these issues before the real ratification process for the agreement would get under way. The need to first subject the deal to a legal review and to translate it and its annexes into 24 official EU languages meant that the CAI was not even going to be a matter of serious consideration until later this year. Some suggest this still gives China and the EU time to find a way to get out of their current impasse.

This is wishful thinking. First, the main proponent and driver of the deal, German Chancellor Angela Merkel, has announced she will step down as Chancellor this fall. Her party has taken a beating in state elections this spring as the German electorate sours on its mishandling of the coronavirus pandemic. Germany's Greens are gaining and could be in a new German government. They are leading critics of the CAI. With Merkel gone and the Greens in power, Germany is less likely to push for CAI ratification without serious revisions.

Second, French President Emmanuel Macron, a CAI supporter, had originally hoped to seal the deal with pomp and flourish by hosting Xi Jinping in Paris during France's Presidency of the European Council in spring 2022. That timing neatly coincides with France's presidential elections. Macron has now discovered, however, that the CAI is not very popular, and his putative opponent Marine Le Pen is using the deal to score points against him. Suddenly, Macron seems less enamored with the CAI and is skeptical that he could derive any potential political gains from it. Paris is now prioritizing the human rights theme.

Third, current tensions have highlighted how the different motivations that initially drove Brussels and Beijing to strike the deal have changed.

Brussels was originally driven primarily by commercial considerations. The EU has hoped that the CAI would open investment opportunities for EU companies operating in the Chinese market and would ensure that EU companies would not be treated worse than their U.S. counterparts. 
The final deal, however, offers minimal opportunities. It does eliminate joint-venture requirements in such sectors as manufacturing, financial and environmental services. It offers some openings for electric vehicles, but on Chinese terms. Procurement markets are still off-limits, and the CAI does nothing to limit harmful Chinese state subsidies that make it difficult for foreign firms to compete with Chinese companies. The EU said the deal would discipline the behavior of China's state-owned enterprises, but China has failed to meet similar commitments it made two decades ago when it joined the WTO, and the CAI's provisions in this area are far weaker than those contained in the Comprehensive and Progressive Agreement for TransPacific Partnership.

CAI codifies market access to foreigners that Beijing had previously granted, for instance regarding cloud computing or private hospitals, without addressing the many bureaucratic hurdles Chinese authorities have erected to stymy foreign investors. For instance, in early December 2020, just before the CAI was concluded, Beijing introduced new regulatory hurdles for foreign investors. And on January 9, 2021, just after the CAI was announced, China announced new rules intended to prevent "unjustified extra-territorial application of foreign legislation," with a mind to averting any future sanctions. What Beijing gave with one hand it took away with another.

This rather paltry result, coupled with China' vague commitments regarding the ILO conventions, stands in stark contrast to the mainly political motivations that drove Beijing to strike the deal. The real attraction of the CAI for Beijing was the opportunity to drive a wedge between the EU and the United States just as Joe Biden was about to assume the Presidency. That is why the timing of the deal was so important. Beijing understood that Biden would quickly seek to re-engage the EU and other democratic allies, both to harness their collective strengths as robust, innovative, and deeply intertwined market economies, and to exert pressure on China in ways that could be more impactful than isolated U.S. or EU approaches. Beijing wanted to preempt Biden however it could.

In sum, the CAI offered Beijing a timely political gain with relatively little economic pain, whereas the EU scratched out some meager commercial gains at a political cost - both in terms of its own professed commitments to human rights and its relationship with the United States.

In just three months, each of these calculations has shifted.

The EU has awoken from its four-year Trumpian nightmare to find a U.S. President who calls Europe America's partner of "first resort" when it comes to global challenges, including those stemming from China. European voices who had called for Europe to disentangle itself from the United States have weakened, as Beijing's hard-line stance stiffens European resolve, and as the Biden Administration has reached out, offering to consult and identify complementary approaches to China, and recognizing and respecting that U.S. and European interests might not always perfectly align.

Many Europeans are wary of locking themselves into a policy of all-out confrontation and containment when it comes to relations with Beijing. But the Biden Administration has been clear it will not try to bully the EU into compliance with U.S. preferences, as Trump tried unsuccessfully to do. 
One early result is that democratic partners are coordinating their China sanctions. Another is that the EU and the United States have agreed to resume and prioritize their strategic dialogue as a means to advance common interests and manage differences on China issues. The transatlantic partners are also now closer than they had been regarding investment screening and placing limits on Huawei's 5G installations on their territories. Brussels has also unveiled a new trade strategy that signals a tougher approach to unfair or exploitative trading practices.

In response to these developments, China has also re-evaluated its priorities. In December 2020 it had calculated that modest commercial concessions via the CAI were worth the political advantages the agreement could bring for Beijing's wedge-driving strategies. Three months later, it has adopted a frontally confrontational course. Its clear priorities are political. It has demonstrated that greater tensions with democracies is an acceptable price to pay for clamping down in Hong Kong, extending its domestic surveillance activities, and sanctioning Australia for a host of political and foreign policy disputes. Should relations sour further with the EU and the CAI be lost along the way, Beijing views that as acceptable collateral damage. It shows no interest in accommodating EU or broader democratic critiques simply to salvage a deal that offered only marginal political advantages that have now evaporated.

Even before the current dispute, MEPs who were involved in the issue had made it clear that CAI ratification would depend in large part on China providing a "road map" for implementing the conventions against the use of forced labor, much as the EU pushed Vietnam to do. They also raised other human rights concerns. The current clash has only heightened their determination to see China take action on these issues. But it has also reinforced China's refusal to countenance such demands. There is little reason to believe that either side will step back this year from what have now become incompatible positions. As a result, CAI is DOA.

Publisher's Note Springer Nature remains neutral with regard to jurisdictional claims in published maps and institutional affiliations. 